UDC 579:662.7

\title{
COMPOSITION OF ABORIGINAL CONSORTIUM OF MICROORGANISMS FROM COAL MINES DUMPS
}

\author{
I. Blayda', T. Vasyleva1, V. Baranov², L. Slysarenko', \\ S. Shulyakova ${ }^{1}$, T. Brodiazhenko ${ }^{1}$ \\ ${ }^{1}$ Mechnikov Odesa National University, 2, Dvoryanska St., Odesa 65082, Ukraine \\ e-mail: iblayda@ukr.net \\ ${ }^{2}$ Ivan Franko Lviv National University, 4, Hrushevskyi St., Lviv 79005, Ukraine
}

The article presents the results of studies aimed at characterictics of quantitative and qualitative composition of aboriginal consortium of microorganisms from coal mines dumps of Lviv-Volynsky coal-basin with different storage time. The defined qualitative composition of substrates' microbiocenosis does not depend on the storage time, because it builds up in a course of substrates' formation and is defined by already established chemical and mineralogical composition of the dumps. It was confirmed that heterotrophic and acidophilic chemolithotrophic bacteria, namely mesophilic and moderately thermophilic genera Acidithiobacillus and Sulfobacillus, are present in the aboriginal consortium of substrates from coal mines dumps. Isolation of the acidophilic chemolithotrophic bacteria from substrates with neutral $\mathrm{pH}$ (from the dumps under study) proves that spreading of these bacteria is much wider than that of naturally acidic ecosystems. It was stated that the neutrophilic thionic and sulphate-reducing bacteria are present in the composition of the microbial association of the studied dumps. The existence of sporulated "silicate" bacteria capable of breaking quartz in the heterotrophic component of microbiocenosis was also confirmed. The study proved that representatives of different groups of microorganisms of the aboriginal microbiota prevail quantitatively in the dumps with long storage time. This is a consequence of substrates' transformations in a course of storage under the exposure to exogenous factors that, in their turn, leads to a greater display of biocenosis in the substrates.

Keywords: coal mines dumps, microbiocenosis, aboriginal consortium, acidophilic chemolithotrophic bacteria, heterotrophic bacteria, neutrophilic thionic bacteria, sulphate-reducing bacteria.

\section{INTRODUCTION}

It is important to know the composition and oxidative activity of the aboriginal microbial associations selected substrates, because it is a key factor which determine speed and depth of the biological leaching of metals for successful application of biotechnology in the processing of natural and man-made materials. The study of microbial

ISSN 1996-4536 (print) • ISSN 2311-0783 (on-line) • Біологічні Студії / Studia Biologica • 2017 • Том 11/№2 • C. 67-78 
composition of naturally occurring minerals indicates the presence of the representatives of mesophilic and moderately thermophilic bacteria oxidizing sulfur and ferrous iron [11, 20, 37]. Evaluation of the biogeochemical activity has showed that under natural conditions these microorganisms played important role in leaching of metals from sulphide ores. Similar processes have occurred in the technogenic wastes which derived from the corresponding natural substrates [16, 24, 29, 41]. The processing of primary mineral raw materials in the hostile environment and further accumulation and preservation of generated waste and heaps with changing of temperature, acidity, content of high concentrations of heavy metals have made conditions for a wide variety of their own microbiota [16, 17, 34]. The problems connected with structure and balance of different groups of microorganisms, physiological and biochemical characteristics and practically useful properties of bacteria which lived in these man-made ecosystems are underexplored $[6,16,30,35]$. This review presents the data on recent progress in the establishment of quantitative and qualitative composition of native microbiocenosis by the rock dumps of prepared coal with different storage time obtained from Lviv-Volyn Coal Basin. These data provide characterictics of the most active and resistant strains of the consortium in the biotechnological processing technogenic substrates.

\section{MATERIALS AND METHODS}

Coal mines dumps of Central Processing Plant (CPP) "Chervonohradska" PAS "Lvivska Vuhilna Kompaniia" with different storage time, for example, red dumps with a long period of storage time (more than half a year) and black dumps with a short period of storage time (less than half a year) were studied. Samples were taken on slopes of dumps from the surface layer to a depth of $20 \pm 5 \mathrm{~cm}$ in June 2014.

The presence of different bacterial groups was determined by standard microbiological methods using a selective culture media [14, 20, 28]. Their composition is presented in the Table 1.

The leaders in leaching of metals were the acidophilic chemolithotrophic bacteria (ACB), including the genera Acidithiobacillus, Sulfobacillus, Leptospirillum, Acidimicrobium, Acidianus, Ferroplasma [12, 14, 20, 24, 28, 38], and for that reason this groups of bacteria were studied. The taxonomy of bacteria of Acidithiobacillus is based on their relationship to energy supply, mineral background of the culture medium with adding ferrous iron compounds in the form $\mathrm{FeSO}_{4} \times 7 \mathrm{H}_{2} \mathrm{O}\left(44.5 \mathrm{~g} / \mathrm{dm}^{3}\right)$, elementary sulfur $\left(5.0 \mathrm{~g} / \mathrm{dm}^{3}\right)$ and sodium thiosulfate $\mathrm{Na}_{2} \mathrm{~S}_{2} \mathrm{O}_{3}\left(5.0 \mathrm{~g} / \mathrm{dm}^{3}\right)[20,28]$. Considering a wide range of temperatures in the rock dumps achieved in a process of accumulation and storage (from 15.0 to $120.0^{\circ} \mathrm{C}$ ) were conducted works to identify bacterial groups that have different relation to temperature. The presence of the mesophilic and moderately thermophilic bacteria of Acidithiobacillus genus was determined on a standard culture medium Silverman-Lundhrema $9 \mathrm{~K}$ and 150a [14, 20, 28]. Using medium 882 [14] is showed the presence of ferrobacteria, including species of Leptospirillum genus, which are the main representatives of ferrobacteria with energy metabolism of the chemolithotrophical type $[18,23,36]$. Whereas these bacteria do not use sulfur as an energy source, so for their indication $\mathrm{FeSO}_{4} \times 7 \mathrm{H}_{2} \mathrm{O}$ was added to medium in a concentration of $20.0 \mathrm{~g} / \mathrm{dm}^{3}$. Using of modified medium $9 \mathrm{~K}^{*}$ [14] showed the presence moderately thermophilic bacteria of Sulfobacillus genus in the waste dumps. This group of bacteria utilizes a wide range of energy sources like sulfur compounds and reducing compounds of sulfur and iron and range for growth is in the range of temperature from 15.0 to $50.0^{\circ} \mathrm{C}[25,36]$. For detection

ISSN 1996-4536 (print) • ISSN 2311-0783 (on-line) • Біологічні Студії / Studia Biologica • 2017 • Том 11/№2 • C. 67-78 
of moderately thermophilic representatives of Acidithiobacillus caldus which are also found in mineral substrates microbiocenosis of natural and technogenic origin 150a selective medium was used [14]. Acidithiobacillus caldus is a chemolithotrophic aerobic microorganism that uses the energy of oxidation of sulfur reducing compounds, but cannot oxidize ferrous iron and the temperature optimum for it is in the range from 40.0 to $50.0^{\circ} \mathrm{C}[33,42]$. $\mathrm{pH}$ value for groups of the mesophilic and moderately thermophilic bacteria was drove to $2.0-3.0$ by adding $1.0 \mathrm{~N}$ solution of $\mathrm{H}_{2} \mathrm{SO}_{4}$.

Table 1. Composition of culture media $\left(\mathbf{g} / \mathrm{dm}^{3}\right)$ for determination of the microbial associations of the dumps

Таблиця 1. Склад поживних середовищ (г/дм³) для визначення мікробних угропувань, що мешкають у породних відвалах

\begin{tabular}{|c|c|c|c|c|c|c|c|c|c|}
\hline \multirow{2}{*}{$\begin{array}{c}\text { Mineral } \\
\text { components }\end{array}$} & \multicolumn{9}{|c|}{ Culture media $[14,20,28]$} \\
\hline & A-27 & Czapek & $9 \mathrm{~K}$ & $9 K^{*}$ & $150 a$ & Beyerink & 882 & 195 & 866 \\
\hline $\mathrm{MgCl}_{2} 6 \mathrm{H}_{2} \mathrm{O}$ & & & & & & 0.10 & 0.053 & & \\
\hline $\mathrm{KH}_{2} \mathrm{PO}_{4}$ & & & 0.50 & 0.05 & 0.50 & & 0.027 & 0.20 & 0.20 \\
\hline$\left(\mathrm{NH}_{4}\right)_{2} \mathrm{SO}_{4}$ & & & 3.00 & 0.45 & 3.00 & & 0.132 & & \\
\hline $\mathrm{MgSO}_{4} \cdot 7 \mathrm{H}_{2} \mathrm{O}$ & 0.50 & 0.50 & 0.50 & 0.50 & 0.50 & & & & \\
\hline $\mathrm{MgCl}_{2}$ & & & & & & & & 3.10 & 0.10 \\
\hline $\mathrm{NH}_{4} \mathrm{CL}$ & & & & & & 0.10 & & 0.30 & 1.00 \\
\hline $\mathrm{KCl}$ & & 0.50 & 0.10 & 0.05 & 0.10 & & & 0.50 & \\
\hline $\mathrm{NaNO}_{3}$ & & 3.00 & & & & & & & \\
\hline $\mathrm{K}_{2} \mathrm{HPO}$ & & 1.00 & & & & & & & \\
\hline $\mathrm{Na}_{2} \mathrm{HPO}_{4}$ & 2.00 & & & & & 0.20 & & & \\
\hline $\mathrm{Ca}\left(\mathrm{NO}_{3}\right)_{2}$ & & & 0.01 & 0.014 & 0.01 & & & & \\
\hline $\mathrm{CaCl}_{2} 2 \mathrm{H}_{2} \mathrm{O}$ & & & & & & & 0.147 & 0.15 & \\
\hline $\mathrm{NaCl}$ & & & & & & & & 21.00 & 5.00 \\
\hline $\mathrm{Na}_{2} \mathrm{SO}_{4}$ & & & & & & & & 3.00 & 5,00 \\
\hline $\mathrm{Na}_{2} \mathrm{~S}$ & & & & & & & & 0.40 & 0.50 \\
\hline $\mathrm{FeCl}_{3}$ & & 0.01 & & & & & & & \\
\hline $\mathrm{FeSO}_{4} \cdot 7 \mathrm{H}_{2} \mathrm{O}$ & & 0.01 & & & & & 20.00 & & \\
\hline $\mathrm{NaHCO}_{3}$ & & & & & & 1.00 & & 5.00 & 8.00 \\
\hline $\mathrm{CaCO}_{3}$ & 1.00 & & & & & & & & \\
\hline Quartz & 10.00 & & & & & & & & \\
\hline Saccharose & 5.00 & 30.00 & & & & & & & \\
\hline Peptone & & & & & & & & 2.50 & 5.00 \\
\hline Yeast extract & & & & 0.02 & 0.02 & & & & \\
\hline $\mathrm{pH}$ & $7.5-8.0$ & $6.6-7.2$ & $1.0-3.5$ & $1.8-4.0$ & $1.5-3.5$ & $4.5-8.5$ & $2.0-4.0$ & $7.5-8.0$ & $7.5-8.0$ \\
\hline $\begin{array}{l}\text { Temperature, } \\
\mathrm{T}-{ }^{\circ} \mathrm{C}\end{array}$ & $\begin{array}{c}30.0-32.0 \\
\pm 0.5\end{array}$ & $\begin{array}{c}28.0-30.0 \\
\pm 0.5\end{array}$ & $\begin{array}{c}32.0-35.0 \\
\pm 0.5\end{array}$ & $\begin{array}{c}45.0-50.0 \\
\pm 0.5\end{array}$ & $\begin{array}{c}45.0-50.0 \\
\pm 0.5\end{array}$ & $\begin{array}{c}28.0-30.0 \\
\pm 0.5\end{array}$ & $\begin{array}{c}32.0-35.0 \\
\pm 0.5\end{array}$ & $\begin{array}{c}28.0-30.0 \\
\pm 0.5\end{array}$ & $\begin{array}{c}28.0-30.0 \\
\pm 0.5\end{array}$ \\
\hline
\end{tabular}

ISSN 1996-4536 (print) • ISSN 2311-0783 (on-line) • Біологічні Студії / Studia Biologica • 2017 • Том 11/№2 • C. 67-78 
Earlier, it was found [9] that the dumps had high amount of sulfur, and pH values were weakly acidic, nearly neutral because it was possible presence in the microbiocenosis of the neutrophilic thionic bacteria. When the Beyerink medium was used showing the presence of neutrophil thionic bacteria which belong to Thiobacillus genus, and they oxidized only sulfur and sulfur compounds. Neutrophilic thionic bacteria can supply the nitrogen compounds to Acidithiobacillus ferrooxidans and speed up the oxidation processes [20,39].

It is known $[2,20]$ that different soils, particularly technogenic, as well as among mineral earth-oil and sulphide ores widespread sulphate-reducing bacteria (SRB), including species of Desulfovibrio genus and Desulfotomaculum genus. Usually, they are located in the niches with low redox potential and neutral $\mathrm{pH} 5.6-8.5$ and developed both at the anaerobic and microaerophilic conditions. Culture media 866 and 195 [14] were used. They contained the main mineral components - a set of phosphates, ammonium salt, potassium, magnesium sulphate, as the electrons acceptor for creating conditions for the accumulation of CSR the genus as Desulfotomaculum as well as Desulfovibrio.

Gorbenko medium was used to determine presence of the heterotrophic bacteria as sporogenous and non-sporogenous type. The culture medium A-27 served to identify "silicate" bacteria that destroy the quartz compounds, feldspar, and other aluminosilicates because these bacteria can stimulate the revealing of natural sulphide ores [1, 19]. Czapek medium served to identify the filamentous fungi.

The accumulating cultures were obtained at standard microbiological methods: in sterile flasks dumps were put and the appropriating breeding grounds in ratio of the solid $(S)$ and the liquid $(L)$ phase $S: L=1: 10$. Groups of the mesophilic, neutrophilic, acidophilic, chemolithotrophic and heterotrophic bacteria were cultivated at $(28.0$ $35.0) \pm 0.5^{\circ} \mathrm{C}$, moderate thermophilic bacteria were cultivated at $(45.0-50.0) \pm 0.5^{\circ} \mathrm{C}$ for 3-5 days. Bacteria development of was judged by $\mathrm{pH}$ change, and the appearance of the oxidation haze and film on the surface of the breeding grounds.

The number of representatives of various community groups of bacteria were determined by seeding 10 times serial dilutions of bacterial suspensions on appropriate solid medium of the same composition. The number of sporogenous bacteria were determined after a preliminary heat treatment at $80.0 \pm 0.5^{\circ} \mathrm{C}$ for $15 \mathrm{~min}$ [28]. Cell and colonial morphology were studied using light PrimoStar PC (Germany) and electronic PEM100-01 (Ukraine) microscopes.

\section{RESULTS AND DISCUSSION}

In this study, for the first time the composition of bacterial groups in coal mines dumps with different storage time were characterized. The aboriginal consortium consisting of the microorganisms of different physiological groups from black and red dumps were isolated by the method of accumulating culture (Table 2).

A large number of identical small Gram-negative short rod-shaped cells by creating conditions for mesophilic ACB was recorded on a standard medium of Silverman-Lundhrema $9 \mathrm{~K}$ containing with ferrous iron, sulfur or thiosulfate as an energy substrate (Fig.1). Their number was higher by 2-3 orders in red dumps (Table 2). Thus, it can be suggested about the presence of Acidithiobacillus ferrooxidans and Acidithiobacillus thiooxidans species in the microbial groups of waste dumps, irrespective of their storage. Also it was stated about the presence of ACB species which grow on 9K medium in coal mines dumps. These are typical inhabitants of the natural sulphide ores.

ISSN 1996-4536 (print) • ISSN 2311-0783 (on-line) • Біологічні Студії / Studia Biologica • 2017 • Том 11/№2 • С. 67-78 

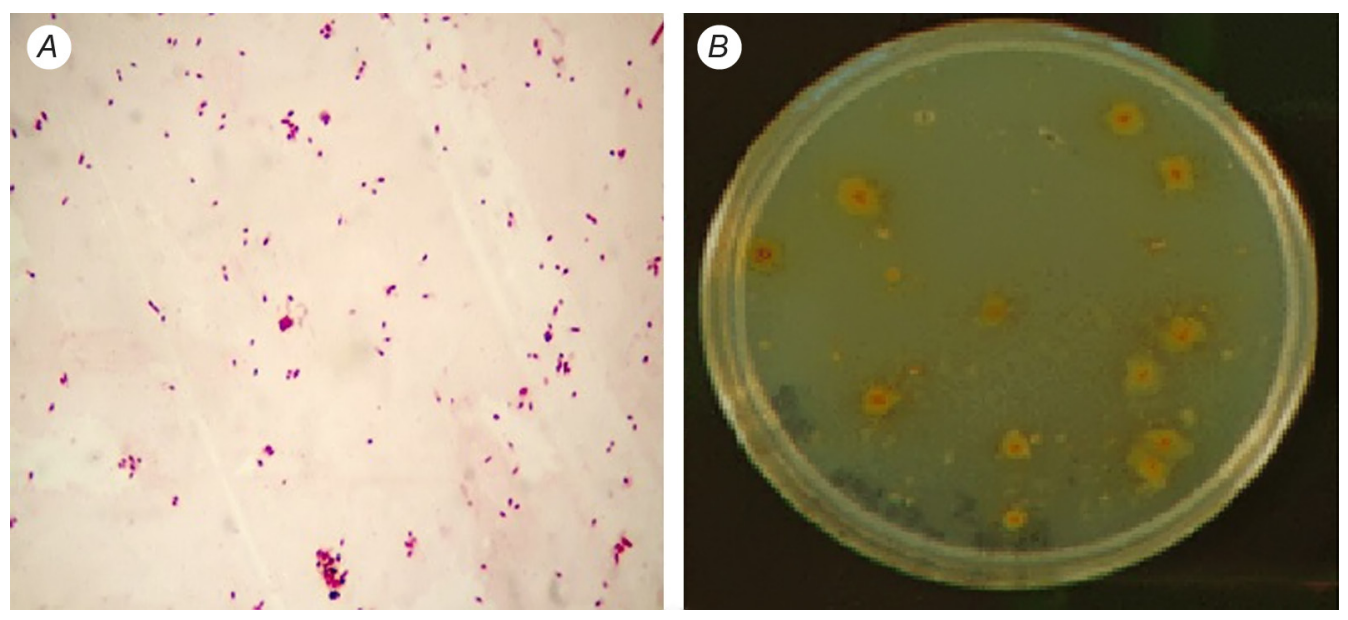

Fig.1. Photomicrography of association of the acidophilic chemolithotrophic bacteriae from red dumps that grew on the culture medium 9K containing divalent iron: $A$ - liquid (×1000 zooming); $B$ - agarized

Рис. 1. Мікрофотографії асоціації АХБ червоного відвалу, що виросли на середовищі 9К з двовалентним залізом: $A$ - рідкому, збільшення $\times 1000 ; B$ - агаризованому

Culture medium 882 was used for growing bacterial suspensions at mesophilic conditions with ferrous iron recommended for Leptospirillum species. Different morphology of Gram-negative cells like small curved bacillus, vibrio and spirillum strains were found. In this medium, the bacterial growth when using sulfur and thiosulfate as an energy source was not observed. This suggests the presence of microbial associations of Leptospirillum ferrooxidans species. They use only $\mathrm{Fe}^{2+}$ as a source of energy, instead of sulfur and compounds of sulfur. The number of bacteria in this group was 1-2 orders smaller than of the representatives of Acidithiobacillus genus, but the trend of greater numbers of bacteria remained in red substrate. Bacteria of the Leptospirillum genus were always present in the mineral raw materials of natural and technogenic origin, but they do not make a significant contribution to the leaching of metals in keeping with numerous published data [18, 27, 36]. However Leptospirillum ferrooxidans increased the efficiency of leaching of the metals associated with Acidithiobacillus ferrooxidans and Acidithiobacillus thiooxidans. These result does not contradict with the current data received.

Weak growth of gram-negative rod-shaped cells at the Beyerink medium with thiosulfate was registered (Fig. 2). Their number was not significant, and it was also higher in red dumps. These results suggest the presence of species of Thiobacillus genus in various man-made waste with different storage time. Similar results were shown in $[25,26]$. It is known [2] that Thiobacillus thioparus in association with Thiobacillus ferrooxidans are active agents in corrosion processes of metallic and non-metallic products. Thus, the presence of neutrophilic thionic bacteria in biocenoses with an overwhelming number of ACB is possible. Also, it was found that the neutrophilic thionic Acidithiobacillus ferrooxidans bacteria can supply the nitrogen compounds and accelerate the oxidation processes $[13,20]$. However, the information is backing about the presence of this bacteria group in the man-made substrates, as well as their ability to leaching metals.

ISSN 1996-4536 (print) • ISSN 2311-0783 (on-line) • Біологічні Студії / Studia Biologica • 2017 • Том 11/№2 • C. 67-78 


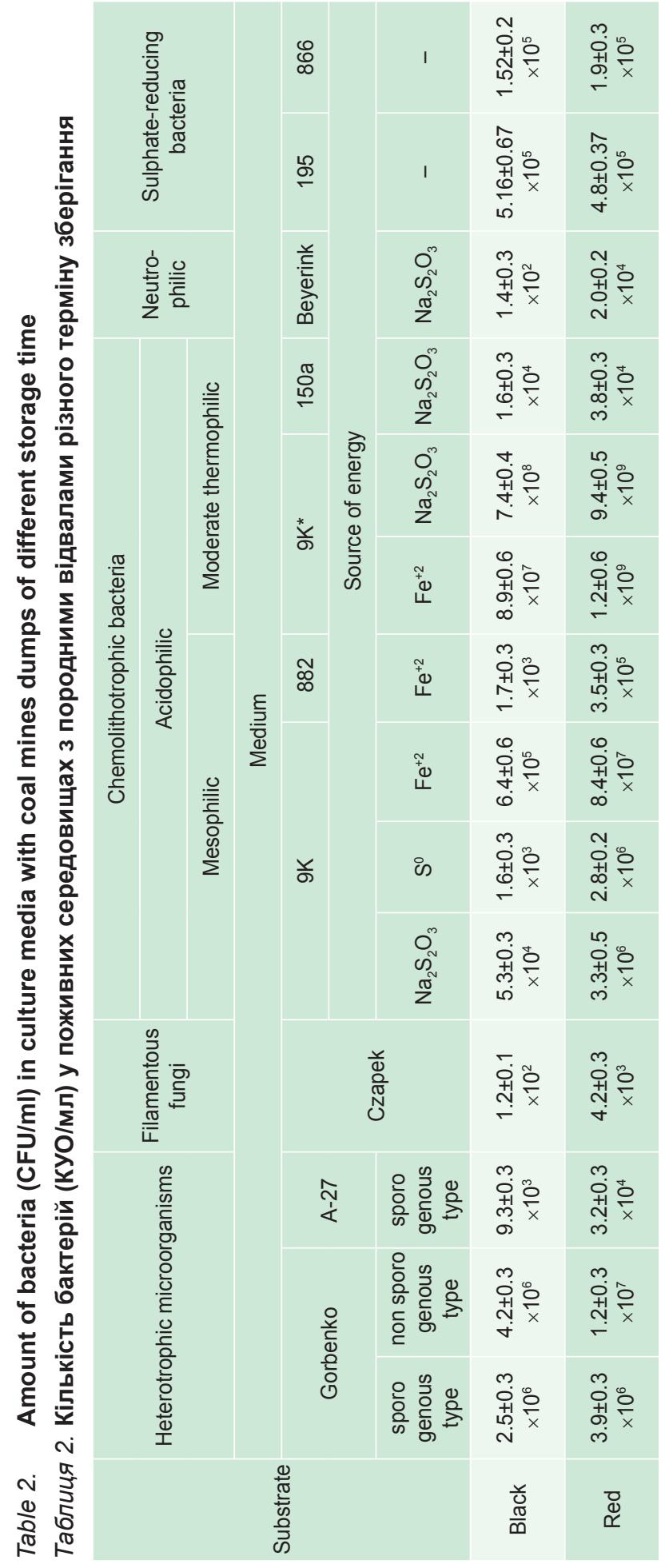

ISSN 1996-4536 (print) • ISSN 2311-0783 (on-line) • Біологічні Студії / Studia Biologica • 2017 • Том 11/№2 • C. $67-78$ 

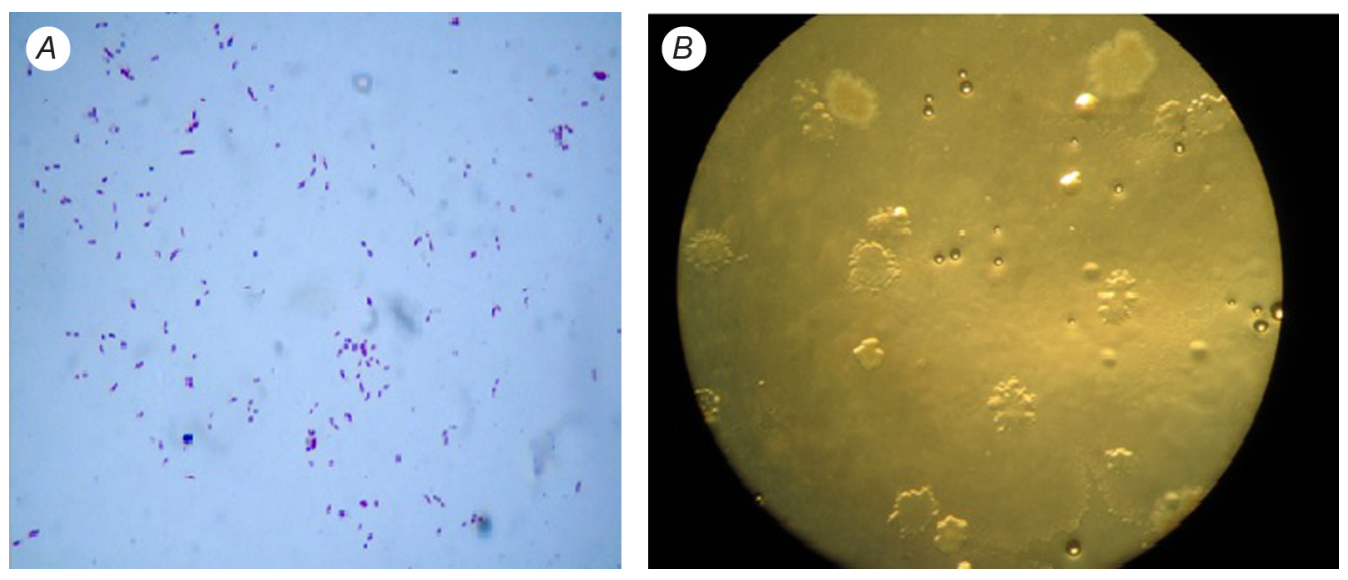

Fig. 2. Microphotography of the association of the neutrophilic thionic bacteria from red dumps that grew on culture medium $9 \mathrm{~K}$ with divalent iron: $A$ - liquid ( $\times 1,000$ zooming); $B$ - agarized

Рис. 2. Мікрофотографії асоціації нейтрофільних тіонових бактерій червоного відвалу, що виросли на середовищі 9К з двовалентним залізом: $A$ - рідкому (збільшення ×1000); $B$ - агаризованому

The presence of species of moderately thermophilic ACB in particular Acidithiobacillus and Sulfobacillus in microbiocenosis of studied substrates was established. In the conditions of our experiments using the medium of the 150a with thiosulfate as a source of energy the accumulating culture with small number of small Gram-negative rodshaped cells independently of the storage time of substrates (titer $10^{4}$ ) was recorded. These results are consistent with published data about a small number of Acidithiobacillus caldus in mineral raw materials of natural and technogenic origin and their limited impact on the extraction of metals from solid minerals. However, Acidithiobacillus caldus in association with Acidithiobacillus ferrooxidans and Acidithiobacillus thiooxidans improve the efficiency of metals extraction [33, 42].

The growth of mainly rounded or short coccoid sporogenous gram-positive cells at modified $9 \mathrm{~K}^{*}$ medium which is recommended for the development species of Sulfobacillus genus, with thiosulfate and divalent iron in mixothrophic conditions was registered. The number of aboriginal moderately thermophilic bacteria was significantly higher in red dumps independent on the source of energy used for the bacterial growth (titer $10^{9}$ ). The comparative analysis of obtained results showed that the number of moderately thermophilic bacteria in the waste dumps was 3-4 orders higher than of the mesophilic bacteria cells. Probably, spontaneous processes contribute to the development of this bacteria group that are constantly occurring in the mines dumps [15].

These results were confirmed by the data that the species of the Sulfobacillus genus are present in the same ecological niches as the thionic bacteria (dumps of sulphide ores, acidic hydrothermal waters, mine waters, deposits of sulphide minerals, where the temperature varies from 10 to $60^{\circ} \mathrm{C}$ ) and were able to oxidize $\mathrm{Fe}^{2+}, \mathrm{S}^{0} / \mathrm{S}^{2+}$ and sulphide minerals [21, 43].

The studied mines dumps contain substances arising as a result of the joint activity of organisms and the abiogenic processes. The intensive development of the heterotrophic bacteria of sporogenous and non-sporogenous types was revealed. The number of heterotrophic bacteria, as well as of other groups, were slightly higher in red mines

ISSN 1996-4536 (print) • ISSN 2311-0783 (on-line) • Біологічні Студії / Studia Biologica • 2017 • Том 11/№2 • C. 67-78 
dumps. The installed capacity of some representatives of the heterotrophic bacteria, like Pseudomonas, of increasing mineral solutions in the presence of microquantity of organic substrates (approx mg/dm ${ }^{3}$ ), as well as the ability of Pseudomonas and Bacillus genera to leach metals, particularly gold and uranium were described [32, 40].

Thus, we found the presence of sporulated "silicate" bacteria in the heterotrophic microbial groups of dumps destroying quartz. The cells looking like classic bacilli of specifically large Gram-positive rods that formed spore's cells which located in bacterial suspension obtained from culture medium A-27 were registered (Fig. 3). They created almost identical round transparent slimy colonies in the agar medium A-27. The number of bacteria of this group was 3.5 times higher in red dumps.
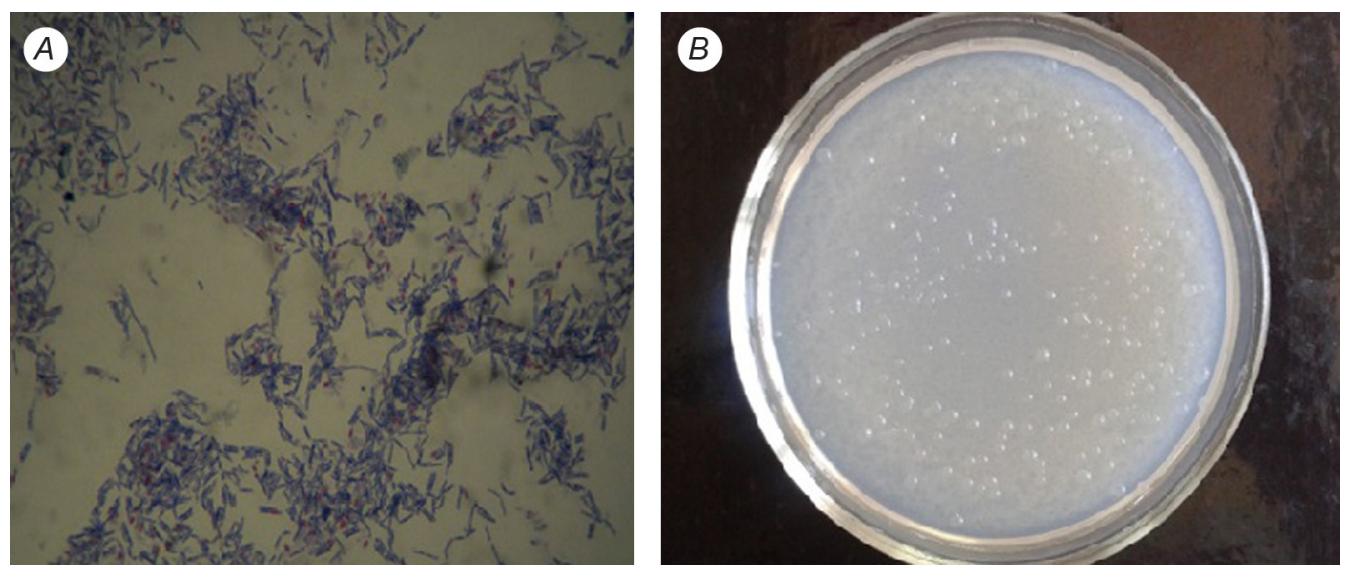

Fig. 3. Microphotography of the association of sporulated "silicate" bacteriae on the culture medium A-27: $A$ - liquid (×1,000 zooming); $B$ - agarized

Рис. 3. Мікрофотографії асоціації "силікатних" бактерій на середовищі А-27: $A$ - рідкому; $B$ - агаризованому; збільшення $\times 1000$

There is a small number of studies on the role of "silicate" bacteria in the process of extracting metals. However, these bacteria take part only in the destruction of quartz $[5,19,22]$. There are no data about the presence of bacteria of this group in the technogenic wastes of coal industry.

Using Czapek's medium, it was found that the composition of the microbial groups in spoil heaps with different storage time include the filamentous fungi, and their number is also higher in red dumps. These results are in agreement with data published in [26].

In our research, the presence of sulfate-reducing bacteria (SRB) in the technogenic heaps of coal enrichment was established for the first time using medium 195 and medium 866. The number of members of Desulfotomaculum and Desulfovibrio genera was $5.16 \pm 0.67 \times 10^{5}$ and $1.52 \pm 0.2 \times 10^{5}$, respectively. The activities of SRB genera (Desulfovibrio and Desulfotomaculum) and thionic bacteria genera (Acidithiobacillus and Tiobacillus), oxidizing sulfur and its compounds to sulfuric acid, and ferrous iron to oxidative iron are known to be associated with the biocorrosion process of metals, stone and concrete structures, and rubber materials [2, 31]. These two groups of bacteria play a leading role in sulfur cycle. The obtained results are in agreement with data of other authors $[25,26]$ and indicate that in the technogenic wastes, there are physical, chemical and biological conditions for different groups of microorganisms about. The

ISSN 1996-4536 (print) • ISSN 2311-0783 (on-line) • Біологічні Студії / Studia Biologica • 2017 • Том 11/№2 • С. 67-78 
presence of the oligonitrophilic and cellulose destruction microorganisms was also in coal mines dumps $[25,26]$.

These studies allow to create a procedure for extraction of indigenous microbial consortia from any technogenic or natural substrate. This procedure involves using a wide range of selective culture media with the addition of various energy sources and creating conditions for specific groups of microorganisms.

As a result of our studies, sustained microbiocenosis composed of different groups of microorganisms in the coal dumps independent on their storage time can by noted. The formation process depended on chemical and mineralogical composition of the dumps. Numerous different groups of the aboriginal microorganisms in red dumps with long storage time are the result of changes that occur during storage of these substrates due to the external factors lead to their higher expression in the ecological community. These results correlate with the existing literature and our own data on physicochemical and biological properties of coal dumps depending on the storage time $[3$, $4,9,10,26]$. It was found [9] that in the dumps with long storage time concentration of the most components and the oxidation of metallic ions of raw materials rises to the highest degree formation of a stable equilibrium. Thus, the effect of the own microbiota of subtracts on the process of leaching of metals from the dumps with short storage time was discovered.

The presence of microbiocenosis representatives of the heterotrophic and acidophilic chemolithotrophic bacteria including mesophilic and moderately thermophilic ACB of Acidithiobacillus and Sulfobacillus genera in coal substrates was confirmed [7]. The secretion of ACB species from substrates with neutral $\mathrm{pH}$ is the evidence that the distribution of active acidophilic chemolithotrophic bacteria is much wider in the acid natural ecosystems. Presence in the composition of microbial associations of the neutrophilic thionic sulphate-reducing bacteria and the presence of heterotrophic sporogenous type "silicate" bacteria that can destroy quartz in coal mines dumps were established.

Taking into account that the microbial community of own microbiota of any substrate that participate in the recovery of metals are of great taxonomic diversity and are interrelatied, this cause syntrophic ratios in the consortium, synergism, mutualism, and competition. It is important to establish a deposit of each identified groups of the microorganisms and their leaching activity. The results of studies of the technological properties of aboriginal representatives of the consortium allow selecting the most active groups of microorganisms in terms of extraction of metals for further isolation of stable fast growing strains and obtaining highly effective unified bacterial drug [8].

1. Avakyan Z.A., Belkanova N.P. Compounds of silicon in solution during bacterial degradation of quartz. Microbiology, 1985; 54(2): 301-307. (In Russian).

2. Andreyuk E., Kozlova I. Lithotrophic bacteria and microbiological corrosion. Kiev: Naukova Dumka, 1977. 164 p. (In Russian).

3. Baranov V. I., Knishl B. Chemical and mineralogical composition of the rock dump coal mines CEP "Lvivsystemenerho" and their effects on seed germination. Industrial Botany: Status and Prospects. Materials V Intern. Science. Conf. Donetsk, 2007. P. 36-37. (In Ukrainian).

4. Baranov V. I. Ecological description of dump coal mines CEP CJSC "Lvivsystemenerho" as an object for landscaping.Visnyk of Lviv University. Biological Series, 2008; 46: 172-178. (In Ukrainian).

5. Belkanova N.P., Karavayko G.I., Avakyan Z.A.The destruction of silicate bond of quartz BacilIus mucilaginosus. Microbiology; 1985; 54(1): 27-30. (In Russian).

ISSN 1996-4536 (print) • ISSN 2311-0783 (on-line) • Біологічні Студії / Studia Biologica • 2017 • Том 11/№2 • С. 67-78 
6. Blayda I.A. Peculiarities of community chemolithotrophic bacteria coal tailing. The Problems of Environmental Biotechnology, 2014; 1. Available at:

http://ecobio.nau.edu.ua/index.php/ecobiotech/article/view/6658. (In Ukrainian).

7. Blayda. I.A. Composition and activity of bacterial community of coal tailing. Biotechnologia Acta, 2014; 7(5): 94-100.

8. Blayda I.A., Vasylieva T.V., Baranov V.I. The use of bio-hydrometallurgical technologies in solving problems utilization of manmade waste and receiving from them valuable metals. Complex Use of Mineral Raw Materials, 2015; 4: 75-82. (In Russian).

9. Blayda I.A., Vasyleva T.V., Chitrich V.F. et al. The physical-chemical and microbiological characteristics of the waste dumps after of coal enrichment. Microbiology \& Biotechnology, 2016; 2: 75-90. (In Ukrainian).

10. Blayda I.A., Vasileva T.V., Semenov K.I. et al. Method two-stage bio-leaching of gallium and germanium. Pat. 104268UA, 2016; 2. (In Ukrainian).

11. Bosecker K. Bioleching: metal solubilization by microorganisms. FEMS Microbiol. Rev, 1997; 20: 591-604.

12. Brierley J.A. Expanding role of microbiology in metallurgical processes. Mining Engineering, 2000; 52(1): 49-53.

13. Burdiyan N.V. Quantitative indices of sulfate-reducing and thionic bacteria in the coastal zone of the Sevastopol water area (the Black Sea). Water: Chemistry and Ecology. Hydrobiology, 2016; 7: 49-55. (In Russian)

14. DSMZ: List of Recommended Media for Microorganisms. https://www.dsmz.de/catalogues/catalogue-microorganisms/culture-technology/list-of-media-for-microorganisms.html

15. Gericke M., Pinches A., van Rooyen J.V. Bioleaching of a chalcopyrite concentrate using an extremely thermophilic culture. International Journal of Mineral Processing, 2001; 62(1): 243-255.

16. Hedrich Sabrina, Schippers Axel. Distribution of acidophilic microorganisms in natural and man-made acidic environments // from: Acidophiles: Life in Extremely Acidic Environments (Edited by: R. Quatrini and D. B. Johnson). Caister Academic Press, U.K., 2016. P. 153-176.

17. Helen R. Watling, Denis W. Shiers, David M. Collinson. Extremophiles in Mineral Sulphide Heaps: Some Bacterial Responses to Variable Temperature, Acidity and Solution Composition. Microorganisms, 2015; 3: 364-390.

18. Hippe H. Leptospirillum gen. nov. (ex Markosyan 1972), nom. rev., including Leptospirillum ferrooxidans sp. nov. (ex Markosyan 1972), nom. rev. And Leptospirillum thermoferrooxidans sp. nov. (Golovacheva et al. 1992). International Journal of Systematic and Evolutionary Microbiology, 2000; 50: 501-503.

19. Karavayko G.I., Belkanova N.P., Eroschev-Shak V.A., Avakyan Z.A. The role of microorganisms and some physicochemical factors of the environment in the destruction of quartz. Microbiology, 1984; 53(6): 976-981.(In Russian).

20. Karavayko G.I. Practical Guide to byoheotehnolohyy metals. M.: ACSSSR, 1989.371 p. (In Russian).

21. Karavayko G.I., Turova T.P., Tsaplina I.A., Bogdanova T.I. Phylogenetic position of aerobic moderately thermophilic bacteria of the species Sulfobacillus, oxidizing $\mathrm{Fe}^{2+}, \mathrm{S}(0)$ and sulfide minerals. Microbiology, 2000; 69(6): 857-860. (In Russian).

22. Karavayko G.I. Microbial destruction of silicate minerals. Proceedings of the Vinogradsky Institute of Microbiology. M.: Nauka, 2004; 12:172-186. (In Russian).

23. Karavayko G.I., Dubinina G.A, Kondrateva T.F. Lithotrophic microorganisms of oxidation cycles of sulfur and iron.Microbiology, 2006; 75(5): 593-629. (In Russian).

24. Kondrateva T.F., Pivovarova T.A., Tsaplinal. A. et al. Diversity of communities of acidophilic chemolithotrophic microorganisms in natural and technogenic ecosystems. Microbiology, 2012; 81(1): 3-27. (In Russian).

ISSN 1996-4536 (print) • ISSN 2311-0783 (on-line) • Біологічні Студії / Studia Biologica • 2017 • Том 11/№2 • C. 67-78 
25. Kuzmishyna S., Hnatush S., Baranov V. Microbiota of the central enrichment plant waste heaps of Chervonograd mining region after coal ash applying. Microbiology \& Biotechnology, 2014; 4: 69-76. (In Ukrainian).

26. Kuzmishyna S., Hnatush S., Moroz O. et al. Microbiota of the coal pit waste heaps of Chervonograd mining region. Visnyk of the Lviv University. Series Biology, 2014; 67: 234-242.

27. Kuzyakina T.I., Haynasova T.S., Levenets O.O. Biotechnology of metal recovery from sulfide ores. Bulletin of Earth Sciences, 2008; 60(120): 76-85. (In Russian).

28. Lengeler Y., Drevs G., Shlegel G. (Ed). Modern microbiology. Prokaryotes. Vol. 2. Moscow: Mir, 2005. 496 p. (In Russian).

29. Leslie Karla, Sturm Arne, Stotler Randy et al. Marinobacter bacteria associated with a massive sulphide ore deposit affect metal mobility in the deep subsurface. Geochemistry: Exploration, Environment, Analysis, 2015; 15: 319-326.

30. Ostash B., GrenT., Beshley S., Baranov V., Fedorenko V. Growth of actinomycetes in vivo and in vitro on the coal waste from central enrichment "Chervonohradska". Visnyk of the Lviv University. Series Blology, 2011; 57: 125-130. (In Ukrainian).

31. Polutrenko M.S. Microbiological corrosion of underground metal structures and methods for their protection. Exploration and development of oil and gas fields, 2012; 45(4): 47-53. (In Ukrainian).

32. Semenchenko G.V., Magomedov D.R., Abubakriev A.T. Use of heterotrophic microorganisms in the leaching of precious metals from sulphide concentrates. Modern resource-saving technologies. Problems and prospects. Materials II International Scientific and Practical Conference. Odessa, 2012: P. 179-185. (In Russian).

33. Semenza M., Viera M., Curutchet G., Donati E. The role of Acidithiobacillus caldus in the bioleaching of metal sulfides. Latin American Applied Research, 2002; 32(4): 303-306.

34. Shiers D.W., Collinson D.M., Watling H.R. Life in heaps: a review of microbial responses to variable acidity in sulfide mineral bioleaching heaps for metal extraction. Research in Microbiology, 2016; 167: 576-586.

35. Tsaplina I. A., Panyushkina A. E., Grigor'eva N. V. et al. Growth of Acidophilic Chemolithotrophic Microbial Communities and Sulfur Oxidation in the Presence of Coal Ashes. Microbiology, 2015; 84 (2): 177-189.

36. Vardanyan N.S., Akopyan V.P.. Leptospirillum-like bacteria and evaluation of their role in pyrite oxidation. Microbiology, 2003; 72(4): 493-498. (In Russian).

37. Vasyleva T.V., Blayda I.A., Ivanytsia V.A. The main groups of microorganisms involved in the biohydrometallurgical process. The Problems of Environmental Biotechnology, 2013; 1. Available at: http://jrnl.nau.edu.ua/index.php/ecobiotech/article/view/4678 (In Russian).

38. Vasileva T., Blayda I., Vasylieva N. et al. The role of mesophilic and moderately thermophilic bacteria in processes of recicling germanium-containing technogenic waste. Complex Use of Mineral Raw Materials, 2015; 4: 59-66. (In Russian).

39. Vaynshteyn M.B. To methods of accounting for thiobacteria. Microbiology, 1981; 50(2): 333-337. (In Russian).

40. Vaynshteyn M.B. Technologies of bacterial leaching of metals. Gold an Technologies, 2010; 2: 48-50. (In Russian).

41. Vaynshteyn M.B., Vatsurina A.V., Sokolov S.L. et al. The composition of bacterial communities in dumps of sulphide nickel ores. Microbiology, 2011; 80(4): 560-567. (In Russian).

42. Zhou Qiu Guan, Bo Fu, Hong Bo Zhou, et al. Isolation of a strain of Acidithiobacillus caldus and its role in bioleachin of chalcopyrite. World Journal of Microbiology \& Biotechnology, 2007; 23(9): 1217-1225.

43. Zhuravleva A.E., Tsaplina I.A., Ismailov A.D. et al. Metabolism peculiarities of the bacteria of Sulfobacillus genus. Advanced Materials Research, 2007; 20-21: 469-472. 


\title{
СКЛАД АБОРИГЕННОГО КОНСОРЦІУМУ МІКРООРГАНІЗМІВ ПОРОДНИХ ВІДВАЛІВ ВУГЛЕЗБАГАЧЕННЯ
}

\author{
І. Блайда', Т. Васильєва', В. Баранов , Л. Слюсаренко1, \\ С. Шулякова ${ }^{1}$, Т. Бродяженко
}

1 Одеський національний університет імені І. І. Мечникова вул. Дворянська, 2, Одеса 65082, Україна e-mail:iblayda@ukr.net

${ }^{2}$ Львівський національний університет імені Івана Франка вул. Грушевського, 4, Львів 79005, Україна

Вивчено кількісний і якісний склад аборигенного консорціуму мікроорганізмів породних відвалів збагачення вугілля шахт Львівсько-Волинського вугільного басейну різного терміну зберігання. Встановлений якісний склад мікробіоценозу субстратів не залежить від терміну зберігання, оскільки формується у процесі їхнього утворення, й обумовлюється сформованим хімічним і мінералогічним складом відвалів. Підтверджено наявність в аборигенному консорціумі субстратів вуглезбагачення представників гетеротрофних і ацидофільних хемолітотрофних бактерій (АХБ), зокрема мезофільних і помірно термофільних родів Acidithiobacillus i Sulfobacillus. Виділення представників АХБ зі субстратів з нейтральними значеннями $\mathrm{pH}$, якими $є$ досліджувані відвали, $є$ свідченням того, що розповсюдження активних ацидофрільних хемолітотрофних бактерій значно ширше за розповсюдження кислих природних біогеоценозів. Встановлено наявність у складі мікробної асоціації досліджуваних відвалів вуглезбагачення нейтрофрільних тіонових і сульфатвідновлювальних бактерій, а також наявність у гетеротрофній складовій мікробних ценозів споротвірних "силікатних" бактерій, здатних руйнувати кварц. Встановлено кількісну перевагу у відвалах тривалого зберігання представників різних груп мікроорганізмів аборигенної мікробіоти, що є наслідком змін, які відбуваються під час зберігання цих субстратів під впливом зовнішніх чинників і призводять до більшого прояву в них біоценозу.

Ключові слова: відвали вуглезбагачення, мікробіоценоз, аборигенний консорціум, ацидофільні хемолітотрофні бактерії, гетеротрофні бактерії, нейтрофрільні тіонові бактерії, сульфатвідновлювальні бактерії

Одержано: 09.06.2017

ISSN 1996-4536 (print) • ISSN 2311-0783 (on-line) • Біологічні Студії / Studia Biologica • 2017 • Том 11/№2 • С. 67-78 